\title{
Orbitocerebral injury by a knife: case report
}

\author{
O. Okay; E. Dağlioğlu; C. Ozdol; O. Uckun; A. Dalgic and F. Ergungor
}

Ankara Numune Education and Research Hospital. Neurosurgery Clinics. Ankara. Turkey.

\section{Summary}

Orbital penetrating injuries may cause significant harm to the optic nerves and eyeball as well as to the brain and cerebral vessels. Management of orbital foreign bodies should include prompt recognition of the extent of the injury, broad-spectrum parenteral antibiotics, tetanus prophylaxis, anticonvulsant medication and early surgical intervention under direct vision to remove the foreign body and to avoid immediate and long-term complications. We report a penetrating orbital injury caused by a bread knife that extended from the orbit to the tegmental dura mater of the temporal bone. The knife's main trajectory coursed through the temporal lobe. Adjacent cerebral structures were explored before removal of the knife.

KEY WORDS: Cerebrum. Eyeball. Orbit. Cranial penetrating injury. Knife.

Traumatismo perforante orbito-craneal por un cuchillo de pan. Presentación de un caso

\section{Resumen}

Los traumatismos perforantes orbitarios suelen causar un daño importante al nervio óptico y globo ocular, así como al cerebro y vasos cerebrales. La órbita permite un acceso fácil hacia la cavidad craneal debido a que tiene una pared ósea delgada y a la presencia del agujero óptico. El enfoque terapéutico de los traumatismos orbitarios por cuerpo extraño depende fundamentalmente del tipo de traumatismo y del cuerpo extraño. El tratamiento de este tipo de lesiones incluirá un rápido diagnostico de la magnitud del daño ocasionado, el empleo por vía parenteral de antibióticos de amplio espectro, profilaxis del tétanos, medicación anticonvulsivante y cirugía urgente que permita, bajo visión directa, la extracción del cuerpo extraño, a fin de

Recibido: 10-07-08. Aceptado: 30-09-08 evitar complicaciones inmediatas o a largo plazo. Presentamos el caso de un traumatismo perforante ocular ocasionado por un cuchillo de pan que se extendía desde la órbita hasta el tegmentum del hueso temporal. El cuchillo seguía una trayectoria directa a través del lóbulo temporal. Se practicó una exploración quirúrgica de las estructuras cerebrales adyacentes para poder extirpar el cuchillo. Se revisan y analizan las opciones de tratamiento de los traumatismos perforantes de la órbita.

PALABRAS CLAVE: Cerebro. Cuchillo. Globo ocular. Orbita. Traumatismo perforante craneal.

\section{Introduction}

Orbital penetrating injuries are uncommon ${ }^{7}$. They may cause significant harm to optic nerves and eyeball as well as to the brain and cerebral vasculature since the orbit provides a vulnerable access to the cranial cavity through its thin bony walls and foramina. Management of orbital trauma depends on the type of injury and on the composition of the foreign body. Injuries caused by metallic objects are infrequent. There seems to be some similarities between metallic and non metallic penetrating injuries in terms of management strategies. We report a 42-year-old man stabbed in his right eye who was admitted to the emergency service in a relatively stable condition. Our case is unique in that the patient was in a stable neurological status despite the severity of the trauma. A wide cranial exposure was carried out for safe removal of the knife.

\section{Case Report}

A 42-year-old man was admitted after being stabbed with a bread knife (Figure 1a). Physical examination revealed the knife handle on the medial epicanthus of his right eye. Neurological examination was completely normal without any focal deficit except visual loss. Exophthalmus, periorbital swelling, amaurosis, subconjunctival hemorrhage, and a dilated unreactive right pupil were 


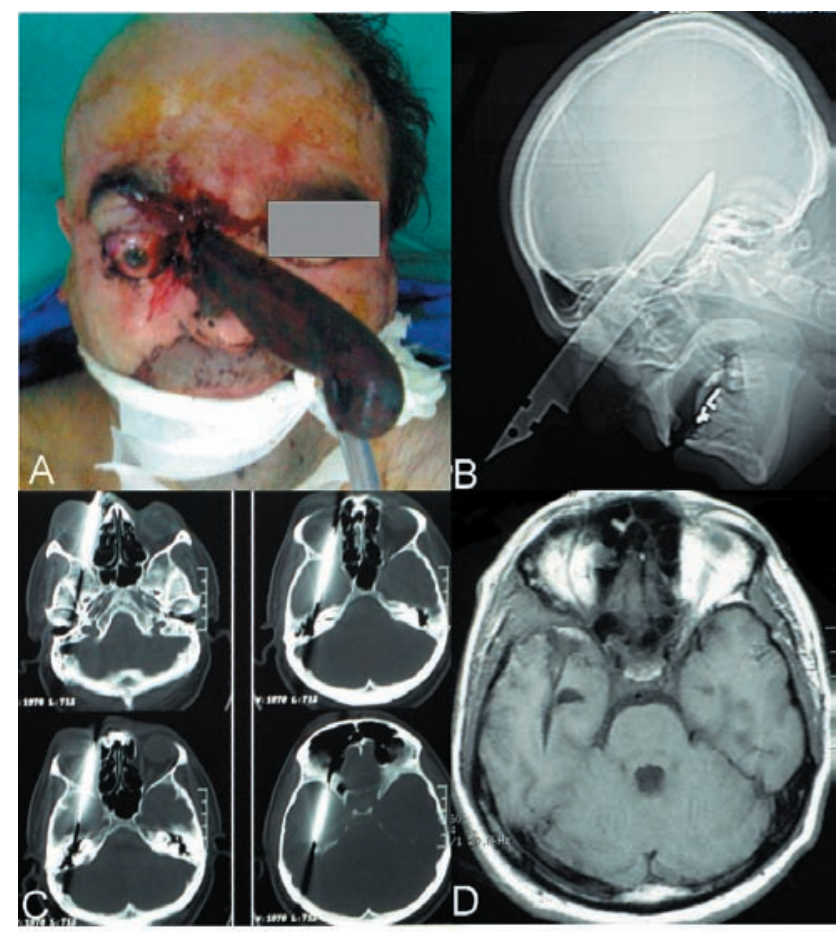

Figure 1. A. Photograph of the patient with the knife handle before the operation. B. CT scan demonstrating the knife trajectory. C. Axial CT scans clearly shows the trajectory through the right orbit to the tegmentum of temporal bone. $D$. Postoperative axial T1-weighted MR image reveals the trajectory of the knife through the temporal lobe.

prominent findings. Plain x-ray and computed tomography (CT) scans revealed that the tip of the knife passed along the posterolateral orbital wall and through the greater wing of the sphenoid (Figure 1b). The CT also showed that the knife had passed through the medial part of the right temporal lobe (Figure 1c). The right ocular globe appeared to be intact but significantly displaced laterally. The right optic nerve seemed to be irregular with a moderate swelling. No other clinical study, like cerebral angiography, was considered since there was no hemorrhage on axial CT scans. The patient was immediately transferred to the operating room. After exploration of the Sylvian region and related arteriovenous structures by a pterional approach, the tip of the knife was shown to be embedded in the tegmental dura of the temporal bone. The knife was removed carefully following the preparation of the route of knife and of the adjacent cerebral structures. There were no signs of vascular or related injuries on the trajectory.

The patient's postoperative course was uneventful and he was discharged without additional neurological deficit except for total visual loss and absence of pupillary reflexes on his right eye. Magnetic Resonance (MR) imaging after 3 months of follow-up showed only residual changes (Figure 1d).

\section{Discussion}

Orbitocranial penetrating injuries are usually associated with a significant morbidity and mortality ${ }^{3,15}$. Most penetrating cerebral metallic injuries are caused by shrapnel or fire arm however wounds caused by knife are rare ${ }^{7}$. Similar orbital penetrating injuries caused by wooden particles, pen or chopstick have also been infrequently reported ${ }^{2,8,10}$.

Radiological studies of orbital penetrating trauma should include a CT exam, plain X-rays, ultrasonography or MR. Plain radiographs may be helpful for identification of fractures and radio-opaque foreign bodies ${ }^{11}$. CT scan is the best radiological method to evaluate penetrating orbital and cerebral injuries particularly caused by metallic fragments since the orbit is an osseous cone. In addition to detecting intraocular foreign bodies, $\mathrm{CT}$ also outlines the trajectory of the penetrating object and depicts eventual associated parenchymal hematomas ${ }^{5,6,12}$. MR images, particularly T1-weighted scans, have proven to be superior to $\mathrm{CT}$ for identifying wooden foreign bodies in the brain parenchyma ${ }^{1}$.

Penetrating orbitocranial injury may give rise to ocular and cerebral injuries like extraocular muscle dysfunction, cranial nerve palsy, optic neuropathy, cerebrovascular injuries, intracerebral hematoma and intraventricular hemorrhage, some of which may require emergent intervention to prevent neurological sequelae $e^{4,5}$. Vascular complications including carotid-cavernous fistula and false aneurysm formation have also been reported ${ }^{4}$. The most serious and potentially fatal complications of orbital penetrating trauma are persistent cerebrospinal fluid leakage and late infective complications including orbital cellulitis, orbital and cerebral abscess, encephalitis and tetanus ${ }^{7,9}$. Unless a foreign particle in the orbit is visualized in anatomical and radiological detail, no surgical intervention is recommended for removal ${ }^{7,13,16}$.

Management of orbital foreign bodies should include prompt recognition of the extent of the injury, administration of broad spectrum parenteral antibiotics, tetanus prophylaxis, anticonvulsant medication and early surgical intervention under direct vision to remove the foreign body and to avoid immediate and long-term complications ${ }^{14}$. The extent of the orbital injury should also be evaluated by the ophthalmologist both for the surgery and for the long-term follow-up ${ }^{1}$.

Late complications like cerebral abscess and caroticocavernous fistula should be considered during the patient's evolution.

\section{References}

1.Bank, D.E., Carolan, P.L.: Cerebral abscess formation following ocular trauma: a hazard associated with common 
wooden toys. Pediatr Emerg Care 1993; 9: 285-288.

2. Davis, G.A., Holmes, A.D., Klug, G.L.: Delayed presentation of transorbital intracranial pen. J Clin Neurosc 2000; 7 : 545-548.

3. Dunya, I.M., Rubin, P.A., Shore, J.W.: Penetrating orbital trauma. Int Ophthalmol Clin 1995; 35: 25-36.

4. Heyworth, P., Kon, C., Tabandeh, H.: Unsuspected orbitocranial injury following ocular trauma. Br J Hosp Med 1994; 51: 174-175.

5. Irshad, K., McAuley, D., Khalaf, K., Ricard, D.: Unsuspected penetrating maxillo-orbitocranial injury: a case report. Can J Surg 1998; 41: 393-397.

6. Lydiatt, D.D., Hollins, R.R., Moyer, D.J., Davis, L.F.: Problems in evaluation of penetrating foreign bodies with computed tomography scans: report of cases. J Oral Maxillofac Surg 1987; 45: 965-968.

7. MacEwen, C.J., Fullarton, G.: A penetrating orbitocranial stab wound. Br J Ophthalmol 1986; 70: 147-149.

8. Matsuyama, T., Okuchi, K., Nogami, K., Hata, M., Murao, Y.: Transorbital penetrating injury by a chopstick-case report. Neurol Med Chir 2001; 41: 345-348.

9. Miller, C.F. Brodkey, J.S., Colombi, B.J.: The danger of intracranial wood. Surg Neurol 1977; 7: 95-103.

10. Nasr, A.M., Haik, B.G., Fleming, J.C., Al-Hussain, H.M., Karcioglu, Z.A.: Penetrating orbital injury with organic foreign bodies. Ophthalmology 1999; 106: 523-532.

11. Ossoinig, K.C.: Detection of wood foreign bodies. Ophthalmology 1991; 98: 274-275.

12. Rosenwasser, R.H., Andrews, D.W., Jimenez, D.F.: Penetrating craniocereberal trauma. Surg Clin North Am 1991; 71: 305-316.

13. Seçer, M., Ergüngör, M.F., Dalgiç, A., Okay, H.O., Daĝlioĝlu, E., Nacar, O.A.: Transorbital brain injury by a metallic fragment: a case report. Turk Neurosurg 2007; 17: 163-165.

14. Vaicys, C., Hunt, C.D., Heary, R.F.: Successful recovery after an orbitocranial injury. J Trauma 2000; 49: 788.

15. Webster, J.E., Schneider, R.C., Lofstrom, J.E.: Observations upon patients with penetrating wounds involving the cerebellum. Ann Surg 1948; 127: 327-337.

16. Wesley, R.E., Anderson, S.R., Weiss, M.R., Smith, H.P.: Management of orbital-cranial trauma. Adv Ophthalmic Plast Reconstr Surg 1987; 7: 3-26.

Okay, O.; Dağlioğlu, E.; Ozdol, C.; Uckun, O.; Dalgic, A.; Ergungor, F.: Orbitocerebral injury by a knife: case report. Neurocirugía 2009; 20: 467-469.

Address for correspondence: Ergün Dağlığlu, MD, Kuzgun Sokak, No.15/14. Aşagiayranci 06540 Ankara. Turkey. 